\title{
Making direct democracy work: a rational-actor perspective on the graphe paranomon in ancient Athens
}

\author{
Carl Hampus Lyttkens ${ }^{1,2} \cdot$ George Tridimas $^{3}$ (D) $\cdot$ Anna Lindgren $^{4}$
}

Published online: 7 June 2018

(C) The Author(s) 2018

\begin{abstract}
The specific way the Athenians set up their democracy presents both theoretical and empirical challenges. Decisions were taken by majority vote in the Assembly. To keep politicians in line, the Athenians first used ostracism, which however was replaced by the graphe paranomon around 415 BCE. The latter provided that anybody who had made a proposal in the Assembly could be accused of having made an unconstitutional suggestion, bringing a potentially severe penalty if found guilty. We know of 35 such cases between 403 and 322. During the fourth century the notion of illegality was extended to a mere question of political undesirability. Henceforth any decision by the Assembly could be overturned by the courts, but if the accuser failed to get at least $20 \%$ of the jury votes, he was punished instead. While these rules can be seen as a safeguard against bad decisions, they also provided the Athenian politicians with important information about the relative strength of their political support. This effect has not been analysed before, and it may help explain the relative stability of political life in classical Athens. Furthermore this analysis also contributes to our understanding of a curious but often overlooked fact, namely that the decrees of the Athenian Assembly to a great extent concerned honorary rewards, and the use of the graphe paranomon in turn was largely focussed on the honorary decrees.
\end{abstract}

Carl Hampus Lyttkens

Carl_Hampus.Lyttkens@nek.lu.se

$\triangle$ George Tridimas

G.Tridimas@ulster.ac.uk

1 Department of Economics, Lund University, Lund, Sweden

2 Department of Economic History, Lund University, Lund, Sweden

3 Department of Accounting, Finance and Economics, Ulster University, Shore Road, Newtownabbey, County Antrim BT37 0QB, UK

4 Centre for Mathematical Sciences, Lund University, Lund, Sweden 
Keywords Ancient Athens · Graphe paranomon - Direct democracy · Judicial review $\cdot$ Voter information $\cdot$ Stability of policy $\cdot$ Jury composition

JEL Classification $\mathrm{N} 4 \cdot \mathrm{N} 43 \cdot \mathrm{H} 1$

\section{Introduction}

Ancient Athens was the quintessential direct male participatory democracy where the demos (the citizens) deliberated and decided on all issues of public interest. Modern scholarship has identified several advantages of direct democracy. ${ }^{1}$ First, the legitimacy and accuracy of the voting outcome, since decisions made directly by voters reflect accurately their preferences solving the well-known principal-agent problem that afflicts voting for political representatives. Second, contrary to elections where voters choose vague party platforms combining a range of policies for different issues, voting directly on an issue "unbundles" choices so that citizens focus on the issue to be decided. Third, direct democracy increases citizen political engagement and knowledge of the issue to be decided (which also leads to a better evaluation of the conduct of politicians).

However, these advantages rest crucially on voters having sufficient information to choose the policy that best serves their interests. Voters may lack the information and sophistication required to decide policy, while elected politicians who develop expert knowledge in public policy issues are better equipped to choose policy. If voters lack that information, the benefits of direct democracy are lost. It is even conceivable that a well-endowed interest group takes control of the campaigning in a direct vote forcing a policy that serves the objectives of the group at the expense of the majority of citizens. ${ }^{2}$ In addition, policy making by politicians allows continuous and fine-tuned choices instead of crude binary, yes-or-no, answers to complex policy issues.

Even the direct democracy of Athens needed to delegate responsibilities to individuals. The Assembly of the demos was not an amorphous mass, nor could it make spontaneous decisions. Solutions to issues of public interest needed to be proposed, implemented and administered. Political entrepreneurs motivated by policy objectives and ego rents emerged who wished to lead and receive recognition as "protectors" of the demos. They debated their proposed policies in the Assembly of the demos and then the Assembly voted. In addition, Athens had to fill public offices including the posts of generals who would lead the army at war, financial officers, councillors to carry out the day-to-day management of the city-state, and many other administrative magistrates.

\footnotetext{
1 See Matsusaka (2004, 2005a, b), Besley and Coate (2008), and Mueller (1996). This literature has developed in relation to direct democracy instruments, like the popular initiative and the referendum, which often supplement decision making in modern representative democracies.

2 See Matsusaka and McCarty (2001) for the case of popular initiatives.
} 
The Athenians knew that deceptive advice from political leaders pursuing private agendas and inappropriate conduct in office would put at risk the democratic constitution and could lead to disaster. They had also realised that unfettered decisionmaking by the Assembly could bring political and legal unpredictability and this uncertainty could have ruinous results. ${ }^{3}$ Two factors compounded the problem of unpredictability of decisions under democracy. First, the composition of the Assembly likely varied from meeting to meeting and the decision taken in one Assembly did not bind the decisions of a future Assembly. Second, the use of simple majority rule instead of supermajority, which has the potential to make voting outcomes more stable, implied that public policy could easily be changed as preferences and experiences changed in society.

Like modern democracies, the Athenians had to establish mechanisms of political accountability. In modern democracies, rejection of a party at the polls is a most effective mechanism. Judicial review of policy and impeachment proceedings against serving public post-holders offer additional means of accountability. In the Athenian direct democracy there was no party alteration in government the way it is understood in modern democracies. Although citizens could vote down proposals, the politicians who proposed them were not voted in or out of office, and if they had lost a vote, they could still propose the same or other policies.

In the fifth century, under certain conditions, ostracism could remove political leaders. Around 415 BCE, another instrument for checking wayward political leaders took over, the graphe paranomon, a prosecution brought by any citizen against a proposer of a measure for being unconstitutional, where the court had the power to annul the decree and punish its proposer. The accusation was either that the decree was unconstitutional or that it was damaging to the interests of the people. In the course of the fourth century, such challenges for illegality were extended from breach of some specific provision to breach of the principles underlying the laws and to the mere accusation of undesirability for political reasons. The result was that, with the exception of appointment of magistrates, any decree carried by the Assembly could be attacked as unconstitutional and could be overturned by an Athenian court (Hansen 1999, pp. 205-208).

In this paper, we study the graphe paranomon in the direct democracy of ancient Athens as practiced in the period 403-322 BCE. ${ }^{4}$ This is the period after the 404 defeat in the Peloponnesian War when the Athenians undertook a major revision of the institutions of their democracy to 322 when defeat by Macedon ended the democracy. We focus on how the graphe paranomon affected some of the information problems inherent in direct democracy institutions.

\footnotetext{
3 Thucydides developed a theory of how the Athenian practice of public decisions made by large numbers of random Assembly-goers could err when the speaker was not in the mould of the virtuous political expert (Carugati et al. 2016b).

${ }^{4}$ Women, slaves and foreigners had no political rights. Nevertheless, to the ancient Greeks, Athens was a democracy and very different from city-states that, e.g., applied property qualifications for political rights.
} 
The present inquiry is a part of a small but steadily growing literature using the methods of modern economics, and social science more generally, to study the ancient world. ${ }^{5}$ This paper argues that in addition to being an instrument to hold politicians to account (as traditionally noted), the graphe paranomon in combination with the way the Athenian appointed those who were to serve as jurors in the courts had several important and previously unrecognized implications for the Athenian society. (1) Using the graphe paranomon on honorary decrees provided information on the relative strength of the popular support for different politicians. (2) The graphe paranomon transferred the political power to the courts, where not only the composition was different from that in the Assembly; but also (3) the outcome of voting was relatively predictable. (4) The use of the graphe paranomon was in practice a convenient political instrument for leaders who had learnt that they had a stable majority in the courts.

The paper is structured as follows. Section 2 presents the institutional structure of the Athenian direct democracy of the fourth century BCE. Section 3 details the special provisions aimed at protecting the democracy, in particular the graphe paranomon. Section 4 looks at extant information about the use of the graphe paranomon. The focus of this procedure seems to be the honorary decrees, a curious fact left unexplored in the literature. In Sect. 5, we offer an economic analysis of the graphe paranomon, and argue that an important side effect of this policy measure was to provide the Athenian politicians with information about the strength of their political support. The specific way the Athenians set up their political and judiciary institutions reduced the uncertainty in political decision-making, and most likely enhanced the stability of Athenian public policy thereby contributing to the relative success of the Athenians in the fourth century.

\section{The institutions of democracy in ancient Athens ${ }^{6}$}

\subsection{The emergence of democracy}

After a period of tyranny, the aristocratic conflicts in Athens brought Kleisthenes of the Alkmaionid family to power in 508/7, but only after his appeal to the common people for support. These actions and the ensuing reforms of Kleisthenes were probably the spark that set off Athens on a path to democracy. ${ }^{7}$ By turning to the common people for support, Kleisthenes set an important example. Over the years to come, members of the elite introduced democratizing measures to gain popular

\footnotetext{
5 D'Amico (2018) and McCannon (2018) in the present volume also examine various aspects of the Athenian legal process.

6 The description of the institutional arrangements in classical Athens builds mainly on Hansen (1999) unless otherwise stated.

7 Kleisthenes did not necessarily have democratic intensions, but even if he did not, his actions probably were instrumental in triggering the move towards democracy (Lyttkens 2013).
} 
support, thereby ironically contributing to a process that meant that there were fewer and fewer institutions that the aristocracy could control directly (Ober 1989, p. 85).

It is only occasionally that we can date the democratizing institutional changes. For example, in $462 \mathrm{BCE}$, the aristocratic council of the Areopagos was deprived of almost all its judicial powers, which were transferred to the Assembly and to courts manned by ordinary citizens. In 451/0 Perikles introduced pay for jurors so that even the poor could afford to serve on the courts. ${ }^{8}$ Offices became in practice open to citizens of all classes. It is generally believed that payment to magistrates was introduced about the same time as for jurors.

Towards the end of the fifth century, the Athenian Assembly had extensive powers. It passed decrees and decided on laws, some of which were inscribed on stone, and could also act as court in political trials. All citizens could attend the Assembly meetings, take part in the debate and vote on the proposals.

The issues taken up in the Assembly were first prepared by the Council of Five Hundred. The Council sent an issue to the Assembly either as a closed choice suggesting what the Assembly should decide, or as an open choice. Each year, 500 Councilors, 6000 potential jurors for the courts, and 600 magistrates were chosen by lot (sortition). The Athenians viewed lottery as democratic, while election was seen as elitist. ${ }^{9}$ A few magistrates were elected, most importantly the board of ten generals. A citizen was only allowed to serve as a particular sortitioned magistrate once in his lifetime; he could serve twice on the Council though not in consecutive years. The consequence of this amazing set of rules of rotation is that about one third of the citizens would have had practical experience of running the democracy. Hansen (1999, pp. 313-314) estimates that every second citizen above 30 would have served on the Council at least once in his life time. This provided a very unusual environment for politics. The way in which the political system worked must have been more widely known and understood than in our modern democracies.

In the decade following the Sicilian disaster in 415-413 BCE there was political turmoil in Athens, including two short-lived oligarchic regimes. The latter of those was set up with Spartan help, but democracy was nevertheless soon restored. During the last decade of the fifth century there were intense debates on the merits of different political system in Athens In the political debates of the fourth century, it was typically claimed that proposals for institutional change represented in fact a return to the times of the early $6^{\text {th }}$ century reformer Solon. This indicates that the Athenians did not consider the reforms as revolutionary shifts that broke with the past, but as evolutionary changes that took place within the confines of the law.

As it turned out, the Athenians however did not simply return to old political and judicial rules. The constitution and laws were revised in 403-399 BCE. A distinction was introduced between laws (nomoi, general permanent rules that apply to all individuals) and decrees (psephismata, applying to a specific person or matter or for a limited period). In 403, the right to pass laws was transferred from the Assembly

\footnotetext{
${ }^{8}$ Cf. Lyttkens and Gerding (2018) for a rational-actor perspective on the politics of Perikles in mid-fifth century Athens.

9 See Tridimas (2012) for a rational choice account of the use of sortition in ancient Athens.
} 
to boards of citizens known as of nomothetai (lawmakers), and most legal cases became exclusively the task for the courts. Psephismata were passed by the people in the Assembly. Around 355 the last of the Assembly's jurisdiction in political trials was transferred to the courts. ${ }^{10}$ The pivotal role that courts played in the fourth century also explains why political life was dominated by the orators who unlike the fifth century statesmen were not elected generals. As Headlam (1891) astutely observed, when elections lack partisanship, accusation and condemnation in the court become the means for hurting political opponents. "The passions which with us find expression at elections could there find no vent except in law - courts ... Political prosecution was the recognised way of injuring an opponent” (p. 36).

\subsection{The Assembly and the courts}

There was ample opportunity for those who wished to bring an issue to the Assembly. In the second half of the fourth century Athens, there were slightly more than forty Assembly meetings ${ }^{11}$ and about 175-225 court days in a year (courts did not meet on Assembly days). Voting in the Assembly was by show of hands. ${ }^{12}$ The magistrates who led the proceedings made a visual assessment of which alternative had the majority - there was no actual counting of the votes. In the courts, on the other hand, voting was by secret ballot. It is likely that many Assembly decrees related to simple, uncontroversial and routine matters, unanimously accepted and quickly disposed of without voting in the Assembly meeting (Hansen 1999, pp. 139-140). As soon as there was one citizen against the proposed decision, however, there would be regular voting. While all adult citizens above the age of 20 years could attend the Assembly, jurors in the courts had to be at least 30 years of age.

All citizens could speak in the Assembly but not everybody did. Those who were consistently active in the Assembly (acting as professional or semi-professional policy makers) are usually called 'speakers' (rhetores-orators) in the sources, but in the modern literature, they are often called politicians, and this is the convention followed here. According to Hansen (1999, Ch. 11), however, there cannot have been more than twenty or so politicians active at any given time, and fewer than a hundred during the whole period 403-322. Although there were no political parties in ancient Athens, a politician might have had some more permanent followers. ${ }^{13}$

\footnotetext{
${ }^{10}$ Canevaro (2015) argues that the ratification of laws by panels of legislators specifically appointed for this purpose and reviews of decrees by the courts through the graphe paranomon did not limit popular sovereignty. Instead, it formalised the right of the demos to introduce new laws and change existing ones. Similarly, Cammack (2017) goes as far as suggesting that judicial panels better encapsulated the rule of the demos, because their members were the common people instead of the political leaders.

11 See Tridimas (2017) for a rational choice analysis of the frequency of Assembly meetings.

12 Votes on ostracism and grants of citizenship, where actual ballots were cast, were important exceptions.

13 Hansen (1999) points out that in addition to the "silent majority" in the Assembly there was also a group of citizens who might on occasion pluck up their courage and speak in the Assembly, but who in no way resembled the politicians and their ambitions.
} 
The courts were trying civil, penal and political cases. Further, they scrutinized the suitability for office of potential magistrates, and their conduct when in office, the so called dokimasia and euthynai procedures respectively. In addition, the Athenians regulated political behavior by the eisangelia eis ton demon-a public prosecution of someone for having engaged in an attempt to overthrow the constitution, for treason, or for political corruption (often used against military commanders). These trials were transferred from the Assembly to the courts in 355 BCE.

Private law suits also had a significant political element. As soon as a politician appeared as a disputant on a court, the trial could become a part of the struggle for power. Those engaged in private suits frequently referred to their own expenditures for the common good to convince the jurors of their value to the community. This does not mean, however, that all private suits were political. On the contrary, it seems entirely plausible that the political cases constituted a small proportion of the total in private law suits. Rhodes (1998) provides a vivid picture of how both public and private law suits could become entangled as prosecutions and accusations exchanged, in particular if those engaged were personal rivals.

A court sat for 1 day only and often handled just one case. This contrasts with the Assembly where a number of issues were dealt with in the space of half a day. At the beginning of each year, 6000 citizens were selected by lot among those willing to act as potential jury members. All male citizens above 30 were eligible. Those who were selected then took the so-called Heliastic Oath. On a court day, the selection of jurors for the courts began by using lottery to decide which of those individuals that (a) were members of the 6000 panel, and (b) had turned up for jury service that particular day were selected to actually serve on a court that day. The total number of jurors needed for a court day was probably around 1500-2000 (Hansen 1999, p. 187); a graphe paranomon required at least 501 jurors. Finally, with the group of jurors for the day selected, these jurors were then (c) allocated to the different courts, again using lottery. An important aspect of the lottery procedures was to prevent bribery.

Jurors were paid 3 obols ( 0.5 drachma), a sum that seems to have remained unchanged from Perikles' time and throughout the fourth century. This implies a gradually reduced compensation rate, given the fact that wages probably increased during the fourth century from 1 drachma to 1.5-2.5 drachmas (Loomis 1998). Payment for those who attended the Assembly was introduced in the 390s, quickly increased to 3 obols, and towards the end of the fourth century had reached the level of 1-1.5 drachmas, largely keeping pace with the wage-increases. This seems to imply that sitting as juror (in contrast to attending the Assembly) became less and less financially attractive over time (depending on one's opportunity cost of time). ${ }^{14}$

\footnotetext{
${ }^{14}$ In addition, the chance of actually being picked for juror service was probably between 33 and $50 \%$ (the number turning up in the morning divided by the number of jurors needed that day). On the other hand, growing Athenian prosperity (Ober 2008, 2015) and a comparatively equal distribution of income and wealth in Athens (Kron 2011; Ober 2015, 2017) may suggest that a growing proportion of the Athenian population could afford to sacrifice a day's wages to serve on the courts (we owe this latter point to an anonymous referee).
} 
In view of the Athenian system of governance described above, it is an important question whether the courts and the Assembly would tend to vote the same way on different issues. There has been much discussion about the socio-economic composition of the juries and the citizens attending the Assembly in ancient Athens, but as yet there is no consensus in the literature.

For the purpose of the present paper it suffices to note that the preferences of jurors and assemblymen differed. This is because of the different age requirements that applied to jurors (30+) and to those attending the assembly (20+). Hansen (1999, p. 181) estimates that that about one third of all citizens were excluded from the courts. It is highly likely that preferences varied with age (because of different experiences in life, different remaining life-span etc.) and that this translates into different preferences of the median voter in the Assembly and the courts respectively. The decision of the Athenians that jurors should be older than the citizen average shows that they were aware that preferences differed with age. Thus, it is to be expected that the Assembly and the courts would vote differently on many issues. In other words, we see the jurors in a court as a largely representative sample of the panel of 6000 potential jurors, but argue that the panel itself was not representative of the Athenian citizens in total, or of those that had chosen to attend the Assembly. ${ }^{15}$

Even if one believes that the rich elite had a significant influence on court proceedings, one should not make the mistake of assuming that only the rich turned up as jurors or constituted a majority in the courts; if nothing else because there were too few of them. Nor should we assume that in court a poor person necessarily voted against the rich (and vice versa).

Finally, Athenian jurors were amateurs rather than legal professionals. In any trial, there were neither lawyers, nor public prosecutors nor judges. As litigants, the rich could also afford to hire orators-speechwriters - to argue in their favour in the court. The forensic speeches did not confine to legal arguments only but made references to the character of the individual tried although it might not have been materially important to the trial. Similarly, the court was not obliged to follow any kind of legal precedent. The broad popular participation and lack of legal expertise characterizing the legal system of Athens implies that the court was an inextricable complement to the democratic constitution.

\footnotetext{
${ }^{15}$ In contrast, Carugati and Weingast (2018, pp. 165-166), maintain that juries were "representative of the Athenian population as a whole." This conclusion is based on the "the absence of explicit biases in terms of provenance and wealth" and that "the likely overrepresentation of older Athenians among jurors" could be "considered more as a requirement than a bias." However, they also note that "because of the different composition of these two bodies, the median in the Assembly might not reflect the preference of the median in court" (p. 173, fn. 29).
} 


\section{The graphe paranomon}

The Athenians were painfully aware that there was nothing preordained about the continued existence of their democracy. In the Greek world at the end of the fifth century, violent change of political regime was common. Hence, policy measures to protect the democracy were presumably welcomed by the majority of citizens. For about a hundred years, ostracism, most probably introduced by Kleisthenes in his reforms of 508/7, was the main safeguard against oligarchic coups in Athens. Each year, at its first meeting the Assembly was asked whether to hold an ostracism vote that year. If the answer was affirmative, then at a later meeting, the citizens could vote on who they wanted banished. A person who was ostracized went to exile for 10 years, but otherwise suffered no loss of property or of citizen rights. Only one person could be ostracized any particular year. There are ten attested ostracisms, the first in 487 and the last in 415 , although the law remained valid until the end of the democracy. ${ }^{16}$ Hansen (1999, p. 205) argues that around the year 415, ostracism was for practical purposes replaced by graphe paranomon as a means to discipline the Athenian politicians. The graphe paranomon was a public prosecution of someone for having made an unconstitutional proposal in the Assembly.

The shift from ostracism to the graphe paranomon changed the focus away from individuals towards decisions. Instead of removing a person from the scene, any number of politicians or others could be punished for making bad suggestions in the Assembly. It seems unlikely to be a mere coincidence that this shift occurred at the time when the Athenians suffered the consequences of what turned out to be an extraordinarily foolish set of decisions, namely to send a large expedition force to Sicily and keep it there for several years. This ended in 413 with the complete destruction of the Athenian land and sea forces in Sicily. Against this background, it must have been attractive to pay more attention to the contents of the Assembly decisions (even though ostracism in principle still was a possibility). In the fourth century, the Athenians regarded the graphe paranomon as the main instrument for protecting the democracy. ${ }^{17}$

The graphe paranomon was a so-called public prosecution, which means that the alleged crime concerned a threat to all Athenians. In classical Athens, there were no public magistrates for prosecuting citizens who tried to overthrow the constitution or committed other crimes; the whole judicial system relied on private initiatives. As with private lawsuits, the graphe paranomon prosecution came from a private citizen.

The principle behind the graphe paranomon was that the people by definition were never wrong, so if the Assembly took a bad decision, it must have been because the citizens had received bad advice from someone who ought to be punished when found out. Consequently, a politician would presumably often prefer not to give

\footnotetext{
16 See Lyttkens (2013) and Tridimas (2016) for an account of the introduction of ostracism as a utility maximizing strategy of Kleisthenes.

17 For example, "abolition of the graphe paranomon is as good as abolition of the democracy" (Demosthenes 58.34, quoted from Hansen 1999, p. 210).
} 
voice to his own proposals, but have someone else to do so. The graphe paranomon provided an opportunity to prosecute anybody who made suggestions in the Assembly (within 1 year). The punishment could be severe, e.g., a heavy fine that left the condemned with a life-long debt to the state, but there are also cases where the punishment was more symbolic (Hansen, 1974, pp. 53, 65).

At the same time, it was not without risk to appear as a prosecutor in a public trial. If the prosecutor did not get at least $20 \%$ of the juror votes he was fined 1000 drachmas (a huge sum in comparison to the daily wage of 1.5-2.5 drachmas) and was no longer allowed instigating such court proceedings. Similarly, if the prosecutor withdrew his accusation, he was also fined 1000 drachmas. The proposer of a decree was liable to be prosecuted up to 1 year after bring the proposal to the Assembly. However, the suit for annulment of the decree could be brought at any time. With a graphe paranomon, a court could overturn any decision by the Assembly. If a person had been condemned three times for coming up with an unconstitutional proposal, he would be punished with (among other penalties) atimia and be deprived of all political rights, the right to legal protection and the right to enter the marketplace and the sanctuaries.

In contrast to ostracism, there was no limit on the number of times graphe paranomon could be used in a year, nor on the number of persons accused. All prominent Athenians, not just politicians, were at risk of banishment by ostracism, but only individuals whose decrees had been passed by the Assembly were at risk from a graphe paranomon. The 10 years absence from politics imposed by ostracism represented a long part of a politician's active career and probably a more severely felt loss than the fine imposed by the graphe paranomon. Finally, the graphe paranomon was a legal procedure which means that defence speeches were made, whereas no such formal debates were made before a vote on ostracism.

The graphe paranomon appears to have been popular: we know of relatively many (35) cases of graphe paranomon between 403 and 322 (Hansen 1974, 1999, p. 205-208). He argues that the notion of unconstitutionality was extended in the course of the fourth century to include plain undesirability. As a consequence, "any decree without exception could be attacked as unconstitutional" (Hansen 1999: 205-206). Nevertheless, as Yunis (1988) shows (see below), the court outcome depended on both illegality and unsuitability of the case. The graphe paranomon thus provided an important link between Assembly decisions, court decisions and Athenian policy. In terms of public decision making, subjecting Assembly decisions to graphe paranomon turned the court into a veto player. Effectively, it imposed a condition of supermajority, which as spatial decision theory shows renders the status quo more stable. ${ }^{18}$ Passing decrees required a majority among the jurors in addition to the simple majority in the Assembly. Similarly to the graphe paranomon which

\footnotetext{
18 The presence of a veto player, like the court, whose ideal policy point is distant from that of the proposer of the policy, like the Assembly, makes significant departures from the status quo difficult implying policy stability (see Tsebelis 2002). But, if the policy positions of the proposer and the veto player are aligned against the status quo, agreement on a new policy is easy to achieve and a policy innovation is observed.
} 
concerned decrees of the Assembly, there was an analogous procedure to prosecute someone for having suggested an unsuitable law (graphe nomon me epitedeion theinai), though it appears that it was not used nearly as much as the graphe paranomon and we know only of six such cases from the orators (Hansen 1999, p. 212).

\section{The honorary decrees: the prime targets of the graphe paranomon}

Combining evidence from literary sources and inscriptions, Hansen (1999, p. 156) concludes that we know of some 766 decisions by the Athenian Assembly between the years 404-322 BCE. The content of these decrees is known in 666 cases. Over the 82 years, there would have been around 30,000 decrees in total (Hansen 1999, p. 156). So our sample comprises roughly $2 \%$ of all decrees. Hansen argues that while the literary evidence is obviously biased, the preservation of inscriptions is random. This seems unfortunately optimistic. One can easily conceptualize several systematic selection processes between the decision itself and our records of it. For example, many Assembly decrees were honorary ones, i.e., they provided for the Assembly to praise some worthy individual and/or, in case of foreigners, to grant him Athenian citizenship. The beneficiaries of such decrees had an obvious personal incentive to ensure that the decision was recorded on stone (perhaps they even funded the inscription privately) lest it be forgotten by later generations. Nevertheless, the surviving Athenian record seems to indicate some interesting features in particular regarding the use of the graphe paranomon.

Table 1 shows the distribution of decrees and graphe paranomon on five categories of issues: (1) honorary decrees including grants of citizenship, (2) war and foreign policy, (3) religion and festivals, (4) finance and public works, and (5) other.

The number of decrees known to us varies substantially across categories (Table 1, first row). What immediately strikes the modern observer is the number of honorary decrees. This category claims the largest share of Assembly decrees-362 honorary decrees (including grants of citizenship) comprising 54\% of the total number of decrees. The material that has come down to us thus suggests that honorary decrees were much more common than the decrees of the second largest group, those dealing with foreign and military policy (192 decrees, $29 \%$ of the total). ${ }^{19}$ With respect to the distribution of the graphe paranomon across categories several aspects seem intuitively plausible (but note that comparing the proportion of decrees being challenged by a graphe paranomon across categories is far from straightforward $\left.{ }^{20}\right)$. It is no surprise that seemingly little controversy surrounded religious

\footnotetext{
19 Hansen (1999, pp. 205-212) argues that this evidence (and also the literary evidence) shows that warfare and foreign policy "was the Assembly's most important field of action." It is not obvious to us how this reasoning goes, unless it is on a priori considerations (e.g., warfare must be more important than honorary statues).

20 The numbers of decrees and the numbers of graphe paranomon are not strictly comparable. They are both biased but we do not know how, only that it is unlikely to be by the same source of bias. The process of preservation differs between inscriptions and literary sources, and the reliance on these sets of sources varies across categories. Approximately $70 \%$ of the decrees are known to us from inscriptions, while the remaining 30\% are quoted, paraphrased or referred in the literary sources (Hansen 1999, p.
} 
issues - we do not have evidence of a single decree of this category being challenged by a graphe paranomon. Conversely, recognising that tax and expenditure policies often generate winners and losers, the substantial number of graphe paranomon directed to public finance issues may be explained by the attempts of those harmed by such measures to reverse their losses.

In the following, we focus on two questions arising from the record detailed in Table 1. First, the relatively large share of honorary decrees in the records of the Athenian Assembly, and second, the reasons why the target for a graphe paranomon so often was a honorary decree, 18 out of our 35 cases or $51 \%$ of the total.

According to Hansen (1999), the frequency of honorary decrees is explained by the nature of the Athenian democracy. Rewards and punishments of individuals was an important and integral part of the Athenian political system, as emphasized by the orators. ${ }^{21}$ The proliferation of honorary decrees does indeed seem like a natural consequence of an important trend in Athenian society. In the fifth century BCE, rich citizens were expected to undertake various duties for the benefit of the whole population. The most important of these so-called liturgies were the trierarchy, i.e. paying for the running costs of a trireme for a year, and the choregia, which financed a performance at one of the religious festivals. To perform such liturgies was seen both as an obligation and as an honour. Originally, this system of "public finance" rested largely on voluntariness. To undertake such expenditures was a way of gaining status and recognition as a leading person in society. However, the system gradually became more like a tax that people tried to avoid. In the fourth century, we hear frequent complaints about "tax evasion", i.e., people trying to avoid these expenditures. $^{22}$

The vast amount of honorary decrees may signal that the status and honour informally accorded to the liturgists were increasingly becoming insufficient as incentives. As a result, in the fourth century, great numbers of decrees bestowed honour on benefactors to the community, awarded them golden crowns or ordered statues to be erected in their honour. ${ }^{23}$ Awarding honorary decrees looks like a reasonable way of trying to sweeten the deal for the rich elite by finding new ways to thank them for their services to the community, and securing their continued support for the democracy. This interpretation goes hand in hand with the observation that the fourth century realities motivated financial and political concessions to the welloff, such as the growing problem with rich Athenians dodging liturgical obligations and the poor being unable to credibly commit not to increase taxation in the future

Footnote 20 (continued)

156). In contrast, information about the graphe paranomon comes almost entirely from the literature (Hansen 1974, pp. 28-41). Specifically, this means that we cannot draw the conclusion that the proportion of honorary issues among the preserved cases of graphe paranomon (51\%) follow naturally from the proportion of honorary decrees $(54 \%)$.

21 Hansen (1999, p. 157); Demosthenes 20.154, 24.215.

22 Gabrielsen (1986) and Lyttkens (1994).

23 Schwartzberg (2004) notes that decrees awarding honours lacked entrenchment clauses (which would provide for the decree not to be amended). She takes that as evidence of the Athenians recognised that the beneficiary might later harm the city, so that the honour could be withdrawn. 
Table 1 Number of decrees and graphe paranomon in different categories in Athens, 404-322 BCE (percentage in brackets, sums along rows) Source: Hansen (1974, 1999, p. 156)

\begin{tabular}{lllllll}
\hline & $\begin{array}{l}\text { (1) Honorary } \\
\text { decree or citi- } \\
\text { zenship grant }\end{array}$ & $\begin{array}{l}\text { (2) Warfare } \\
\text { and foreign } \\
\text { policy }\end{array}$ & $\begin{array}{l}\text { (3) Religion } \\
\text { and festivals }\end{array}$ & $\begin{array}{l}\text { (4) Finance } \\
\text { and public } \\
\text { works }\end{array}$ & (5) Other Total \\
\hline $\begin{array}{l}666 \text { decrees } \\
35 \text { graphe } \\
\text { paranomon }\end{array}$ & $\begin{array}{l}362(54 \%) \\
18(51 \%)\end{array}$ & $\begin{array}{l}192(29 \%) \\
4(11 \%)\end{array}$ & $\begin{array}{l}35(5 \%) \\
0(0 \%)\end{array}$ & $\begin{array}{l}17(3 \%) \\
5(14 \%)\end{array}$ & $\begin{array}{l}60(9 \%) \\
8(22 \%)\end{array}$ & $35(100 \%)$ \\
\hline
\end{tabular}

(Lyttkens 2013). A further reason is that Hellenistic copyists (to whom we owe the survival of the Attic orators' texts) were interested more in the clash of personalities than in the subtlety of Athenian policy. ${ }^{24}$ However, none of these interpretations answers our second question of why the use of the graphe paranomon was so concentrated on the honorary decrees, nor does it explain why the graphe paranomon was so popular.

Hansen (1999) argues that the graphe paranomon was used surprisingly often. "We possess no fewer than thirty-five examples of its use in the period 403-322, and that is a very large number if one thinks how limited our sources are" (Hansen, 1999, p. 208, emphasis added). Furthermore, "the vast majority of Athenian political leaders must, at least once and often more than once in their careers, have been sent before the courts to defend the proposal that they had made in the Assembly [...] There is nothing against supposing that the jurors must have judged a graphe paranomon something like once every month." If this figure is in the right order of magnitude, as seems likely, the total number of graphe paranomon in the period 403-322 would have been in the order of 800. The graphe paranomon would certainly have been a conspicuous feature in the political life of the Athenians. What made it so?

\section{Understanding the use of the graphe paranomon}

\subsection{Thinking twice}

The most obvious feature of the graphe paranomon is that it provided the Athenian citizens with an opportunity to think once more about an issue. This probably seemed sensible and important. ${ }^{25}$ For example, Thukydides (III. 1-49) tells us how the Athenians in 427 BCE decided in an Assembly meeting to punish the inhabitants of Mytilene by killing all men and selling the rest of the population as slaves, and it was pure luck that gave them an opportunity to change this decision before it was implemented. Another well-known example of a hasty decision is when eight of the

\footnotetext{
${ }^{24}$ We owe this point to an anonymous referee.

25 Cf., e.g., Kahneman (2011) on the difference between reflected and hasty decisions.
} 
victorious Athenian generals after the battle of Arginoussai in $406 \mathrm{BCE}$ were collectively sentenced to death because they failed to pick up survivors (Xenophon, Hellenika 1.7.1-35). This decision probably left the Athenians virtually without naval military competence (making the defeat against Sparta almost inevitable).

Since the graphe paranomon meant that an Assembly decision would be reviewed by an Athenian court, the graphe paranomon was by definition a kind of judicial review, as noted in the literature. In the modern world, this form of review can be seen as an insurance against radical changes in policy (Tridimas 2010). Although this is not strictly applicable to ancient Athens, we can reasonably argue that the possibility to appeal a decision in the Assembly to a court is also a kind of insurance, namely against too hasty decisions. It must also have forced politicians to think more carefully about the contents of their proposals, probably preventing them from bringing proposals that would have had slim chances of passing. Similarly, the characterization of the graphe paranomon as a judicial review needs to be informed by the Athenian context. As already described, the judicial body was not independent of the current government in the modern sense of the word. In Athens there was no high court with judges on life-time tenure. The composition of the body where the judicial review took place (the Athenian courts) resembled the Assembly itself in that it was a sample of the population at large, but as already described it also differed in composition from the Assembly (cf. below).

The graphe paranomon could be initiated any time after the proposal had been made. This gave the voters an opportunity to investigate the consequences and evaluate ex post whether the policy agreed with their preferences. The graphe paranomon provided an instrument to punish those who turned out to have given bad advice (provided that the procedure was initiated within a year from the proposal in the Assembly). The evaluation was complex as the outcome depended not only on the efforts of the politician but also on the influence of unpredictable exogenous factors. Graphe paranomon reviewed both legislation (as in standard judicial review) and politicians (as in political accountability of politicians who proposed measures to the Assembly).

Yunis (1988) divides the review into two parts, a legal plea, where the decree under indictment is in conflict with one or more laws, and a political plea, where the decree was inexpedient for the Athenians (and if it granted citizenship, the beneficiary of the grant was unworthy of it). He argues that both parts were necessary. The legal issues were assessed against the communal law code and the political issues against the community's best interests, although some tension between them was not precluded. For Schwartzberg (2004) the punishment implied by the procedure resulted in increasing the credibility of existing laws. Specifically, during the fifth century direct democracy there were few, if any, effective constraints on the Assembly to change any law in response to new circumstances, because of the application of the simple majority rule and of the changing composition of the Assembly from meeting to meeting. The ensuing flexibility of laws voted implied legal uncertainty and unpredictability.

Not all ancient historians subscribe to the view that Athens operated judicial review. Cartledge (2016, p. 223) writes: "there was no modern notion of the separation of powers in the Classical Athenian democratic polis, and no Supreme Court." 
Since it was the demos who decided in the Assembly and the demos who judged in the courts, separation of powers was not clear-cut. Nevertheless, this does not negate the fact that the demos-in-court could review and override the demos-inassembly. Moreover, the demos-in-court did not pass new measures, it only decided on whether the decree of the Assembly stood or had to be annulled and its proposer punished. Hence, as already said, the graphe paranomon acted as a supermajority requirement.

A politician could be involved at several stages of the "graphe paranomon-honorary decrees" game. He could have been the honorand, the original proposer in the Assembly, or the instigator of a graphe paranomon against the proposer. He could have encouraged one of his supporters to propose a decree (so that he would not have been prosecuted) and then, if necessary, argue in favour of the proposal in the Assembly and the court. What matters for our analysis is not so much the identity of the honorand, but the involvement of politicians in graphe paranomon related to honorary decrees.

In his discussion of the graphe paranomon, Hansen (pp. 209-210) enumerates several ways in which the graphe paranomon could have improved the decisions of the Assembly in the eyes of the citizens. Jurors had to be 30 years of age. There was great respect for the wisdom of the elderly, "the bald heads and the grey beards". Older folk had a richer experience of fighting wars, good and bad harvests, changing personal fortunes and speeches by politicians to make them more careful and less hasty in judging disputes. A court usually spent considerably longer on a particular issue than the Assembly, and the parties could prepare themselves before the debate in the court. Finally, the court vote was secret and the votes were actually counted, which is more likely to reflect true preferences than a show of hands.

All this may all be true, but it still cannot explain why the graphe paranomon so often concerned honorary decrees, unless politicians simply grabbed every opportunity to strike against each other. The latter explanation seems to be advanced by Hansen (1999, p. 210) when he states that "the frequent use of the graphe paranomon is doubtless due to the fact that in Athens there was often sharp conflict between groups of political leaders. The group that lost a vote in the Assembly often refused to accept defeat and made use of the possibility of appeal to the courts." However, a more articulate explanation requires a more systematic statement of the net benefits that politicians derived from using the procedure.

Suppose an Athenian citizen considers proposing in the Assembly that honours should be bestowed upon somebody. The costs are easy to see: he would run the risk of being punished through the graphe paranomon trial. The benefits are less clear but there must have been some, otherwise why would anyone ever make proposals in the Assembly? Most probably they related to the gratitude of the beneficiary of an honorary decree towards the proposer and even more so upon realising that the proposer took a risk by suggesting the decree. This may be politically important, not least because the beneficiaries of honorary decrees were rich individuals who had 
financed important projects. ${ }^{26}$ This may explain why an Athenian politician would take the risk of being impeached under a graphe paranomon. It comes as no surprise that among the 35 cases of graphe paranomon identified by Hansen, several of the decrees were intended to confer honour to more than one person (6 out of 18 honorary decrees). This would create large numbers of thankful beneficiaries.

\subsection{Modelling the political market in Athens}

We assume that a politician derives utility from the status accorded to the person in charge of Athenian policy (winning votes) but also from the pursuit of specific policy goals. ${ }^{27}$ Additionally, some of the politicians who made proposals to the Assembly probably profited from their political activities; for example, Demosthenes is reported to once having been paid for not taking part in the debate in the Assembly (Hansen 1999, 274-276). To simplify, but without loss of generality, we proceed by assuming two competing politicians. Both politicians and voters are assumed to be rational, by which we mean that they have reasonably well-defined preferences over outcomes.

The likelihood that a citizen would vote for a proposal is assumed to depend on two factors. (a) His utility from the likely effects of the proposal. (b) The characteristics of the politician making the proposal, including his perceived character, competence and reputation. The citizens would often have had limited information about the issue at stake in a debate in the Assembly, and they would therefore look to the politicians for guidance.

That character and reputation were important is illustrated by the fact that when politicians engaged in court disputes (either public or private), they emphasised their own reputation was good in contrast to that of their opponents. For example, in a dispute over inheritance, one finds arguments concerning the politician as a person, whether he had paid his taxes, had taken on liturgies, was kind to family and friends, and did not show immoral sexual behaviour, none of which would have had anything directly to do with the inheritance. ${ }^{28}$ When choosing whether to support a particular leader or his opponent, the voters' perceptions of the different leaders and their previous proposals would be important.

\subsection{Pitfalls of direct democracy}

Carugati et al. (2016a) suggest that there are two major threats from judicial review of the Athenian kind in a direct democracy. First, there is the partisanship threat, i.e.,

\footnotetext{
${ }^{26}$ Of the identifiable proposers and accused in Hansen's collection of graphe paranomon, roughly 50\% appear in Davies' (1971) Athenian propertied families.

27 For a recent statement of this assumption in the context of the Athenian legal process, see Carugati and Weingast (2018).

28 To the extent that these aspects were not included in the laws of the Athenians but nevertheless affected verdicts, courts enforced social norms (Lanni 2009). In so far as these "irrelevant" factors were taken into account by the jurors, ancient Athens was not entirely "ruled by law." Cf. also Rhodes (1998).
} 
the possibility that the (poor) majority uses its political power to benefit themselves at the expense of the rich minority. This may cause the rich minority to attempt a drastic and fundamental change in the rules of the political game, in short, to abolish democracy by unconstitutional or violent means. Such internal conflicts are detrimental to social peace and economic growth. However, for their two centuries of essentially democratic rule, with the exception of the two oligarchic episodes in 411 and 404, the Athenians avoided violent internal conflicts (stasis). The absence of violent internal conflicts was arguably an important contributory factor to Athenian success vis-a-vis their contemporary competitors. The graphe paranomon was an integral part of this balance between the rich and the poor. Stylistically, if the Assembly dominated by the poor and passed a decree ruinous to the rich, the graphe paranomon offered an opportunity to redress excesses.

The second threat pointed out by Carugati et al. (2016a) is the risk that decisions may be inconsistent and unpredictable. They show that policy proposals in a direct democracy will not necessarily converge upon the preferences of the median voter. An implication of this is that a small shift in majority could lead to substantial changes in policy. This could be both disruptive and costly and a threat to the survival of democracy. At first sight, a democracy of the Athenian type seems predestined to suffer from inconsistent and highly variable policies.

Athenian politicians had limited information about the distribution of preferences in society in general (even though they arguably, given the small size of the citizenry, had better knowledge than politicians in a modern parliamentary democracy). Similarly, the distribution of preferences among those who attended the Assembly would only be imprecisely known. It is not unlikely that majority outcomes swung substantially in the short-run between consecutive meetings of the Assembly, especially since there was no mechanism to stop someone from proposing to change a previous decision (even a recent one), once again implying decision instability and a waste of resources. This issue has attracted much less attention in the literature than the partisanship threat. We do not know how much the composition of the Assembly varied in the short run, nor could an Athenian politician have known this with precision, though presumably they knew a good deal about the extent to which it was likely that the same people appeared in the different Assembly meetings. An Athenian farmer often faced a considerable opportunity cost to attend the Assembly and thus could be expected to travel to the Assembly mostly on special occasions. There would likely have been a non-trivial seasonal variation in the attendance. It would have been difficult for politicians to predict how the voters in the Assembly would choose, in particular if the issue was a complex one, like going to war.

\subsection{Voting on honorary decrees and the support for the politicians}

However, the situation would be substantially different if there was an issue of no particular interest to the voters. In this case, voting on the issue would largely be determined by the politicians' characters and reputations. As a result, voting on issues that the citizens did not care much about would produce information about the reputation of politicians. We suggest that the honorary decrees could constitute 
a reasonably good approximation of such an issue. Arguably, the Athenian voters did not much care whether a particular person was honoured or not (whereas issues of, e.g., foreign policy could affect individual welfare considerably). Consequently, voting on an honorary decree would likely be determined by the reputation of the politicians concerned. ${ }^{29}$

Further, a court decision on an honorary decree with two politicians opposing each other would tell the politicians a lot about their relative support among the jurors in the court that day. Following the court ruling, it seems reasonable to argue that information about the current reputation of the politicians would enable them to make a more accurate prediction of their support for policy issues in the future. Hansen (1999, p. 211) states: "An honorary decree was a sort of a vote of confidence by the Assembly, but it could be attacked in the court, and that turned the court into a political forum and its condemnation into a vote of censure". Hence, the verdict of the court depicted most accurately voters' perceptions of politicians. With a graphe paranomon tried "like once every month" in front of a minimum of 501 jurors, it is reasonable to assume that information about the preferences of the 6000 jurors would improve substantially and quickly during an administrative year, as new court decisions based on new samples (from the same 6000 panel) became known.

In contrast to the preferences of Assembly voters, some information regarding the preferences of the jurors of the courts was thus easier to ascertain. To see this, suppose that there are two kinds of citizens in Athens: those who support politician A and those who support politician B. With p the share of supporters of A, the share of supporters of B is (1-p). In any particular year, there will soon be very little uncertainty regarding who will win the vote in a trial where A confronts B. Suppose the court consists of 501 jurors (the minimum number of jurors for a graphe paranomon). If politician A has the backing of, e.g., $51 \%$ of the members of the 6000 panel, then the probability that he will win in the court is $68 \%^{30}$ (Fig. 1). Overall, with a jury this size, it is only if the share of supporters between two politicians is relatively equal and lies between-say-45-55\%, that the Athenians would experience uncertainty as to which politician will win. As we can see in Fig. 1, if a politician has the support of $40 \%$ or less of the panel members he will (almost) never win, and if he has the support of $60 \%$ or more, he (nearly) always wins. ${ }^{31}$

${ }^{29}$ Of course this begs the question of why rational voters, who appreciate that the probability of casting
the decisive vote was negligible, would turn up and vote in the Assembly. The answer here lies not only
on the fee for attendance paid to first six thousands attending the Assembly, but also on the fact that each
Assembly meeting dealt with both honorary decrees and "bread and butter" policy issues, as well as the
intrinsic utility from participating in the democratic process.
30 The distribution of the number of selected jurors that will vote for politician A follows a Hypergeo-
metric distribution. The probability that politician A will win is the sum of the probabilities of him hav-
ing 251 through 501 supporters in the jury. With $51 \%$ of the panel, i.e. 3060 members, supporting politi-
cian A, and the remaining 2940 members supporting politician B, the probability of politician A getting the majority of the 501 members of the court jury is $\sum_{k=251}^{501} \frac{\left(\begin{array}{c}3060 \\ k\end{array}\right)\left(\begin{array}{c}2940 \\ 501-k\end{array}\right)}{\left(\begin{array}{c}6000 \\ 501\end{array}\right)}=0.68$.

31 For example, with the support of $40 \%$ of the panel, the probability of winning in the court is 1 in 900,000 . 
We conclude that it would quickly have become obvious who would win in the courts if two politicians were pitted against each other. This information could be elicited by involving one's opponent with a graphe paranomon dealing with an honorary decree. Obviously, the Athenians did not have the mathematical tools that we have, but they did have several decades of experience of how their institutional system worked. It is hard to believe that the more astute among the Athenian politicians did not have a good feeling for how these mechanisms worked.

It is an interesting possibility that the reason why the graphe paranomon was often used in connection with honorary decrees was not that these honorary decrees were important issues in voter preferences about policy, but because it could reveal trust and support for the politicians. To initiate a graphe paranomon dealing with an honorary decree can be seen as a test to find out how the current-year panel of potential jurors assessed the character reputation of various politicians. This would be a useful device for eliciting information regarding political support which could be used for the rest of the year, in particular when major political issues were at stake. ${ }^{32}$ Using graphe paranomon to challenge other types of decrees (non honorary) could also offer information on support for politicians, although the picture then was more complicated, since the prosecution would also relate to the policy content of the decree.

\subsection{Running a democracy through the courts}

Athenian politicians must have been aware that preferences differed among those sitting in the courts and those attending the Assembly, because of the difference in age structure and the different levels of monetary compensation in conjunction with the different earning capacities of the participants. These differences opened the possibility that a proposal that received a majority in the Assembly could be overturned by the court. Furthermore, the politician who had the strongest backing in the courts were likely to be the one who was most influential in Athens, rather than a politician who tended to win votes in the Assembly. Suppose, for example, that it had become known that one of two leading politicians had a better reputation than the other. Both politicians would have realised this. The politician with weak support in the courts would have great difficulties in pursuing his political aims. Even if he won in the Assembly, his opponent could always transfer the matter to a court by using the graphe paranomon, where it would be struck down. At the same time, there was no risk that a proposal from the politician with a substantial majority in the courts that won the Assembly vote would be overturned by a court.

\footnotetext{
32 Although not specifically talking about honorary decrees, Carugati et al. (2015) reach a similar conclusion regarding the ability of the Athenian judicial system to reveal information regarding the views held by the community. They argue (p. 317) that "Because [jury decisions] were the product of large, representative panels of jurors voting through majority rule, secret ballot and without deliberation, jury verdicts were consistent with broad community expectations concerning the norms and laws at issue in a given court case."
} 


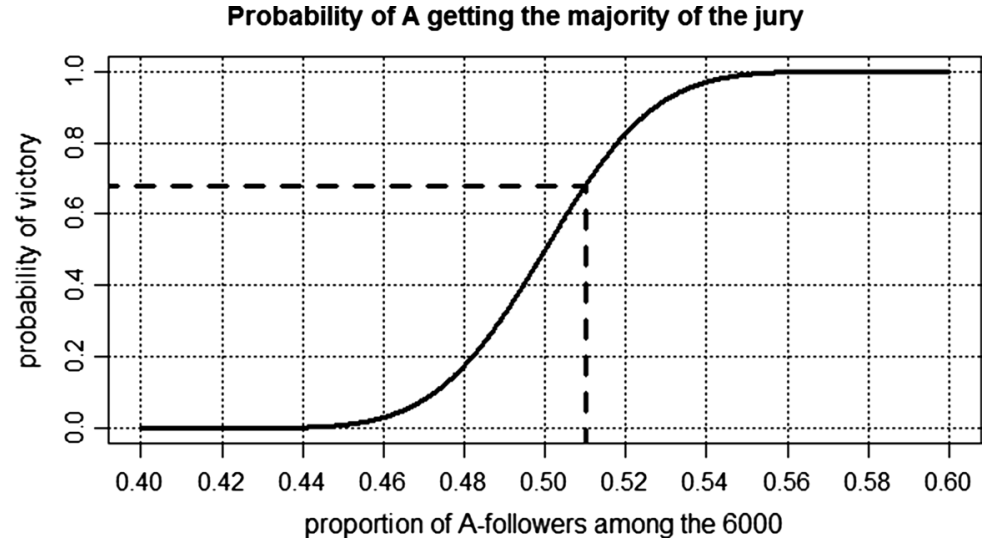

Fig. 1 Probability of winning the vote in a court with 501 randomly drawn jurors, depending on the share of supporters among this year's 6000 potential jurors

With a majority in the courts, a politician faced a negligible risk that he would be unable to muster the minimum of $20 \%$ of the votes and so he was safe from repercussions by not attracting enough votes in a graphe paranomon. Most likely, this must have been one of the major factors behind the extensive use of the graphe paranomon. In practice, politicians initiating a graphe paranomon did not risk suffering from any disadvantages for having done so. In contrast, someone who could rely on a majority in the Assembly but had only minority backing in the courts would find it difficult to influence Athenian policy, and ran a considerable risk of being prosecuted and found guilty in a graphe paranomon.

This brings the selection of the members of the 6000-panel to the fore, and more specifically whether its membership overlapped over consecutive years. If, as one may reasonably expect, politicians recognised that the 6000-panel of jurors was highly important, they must have made every effort to get citizens that shared their views to try to participate on the panel. Of course, packing a particular court with someone's supporters would have been a nearly impossible task given the large number of jurors involved and the random selection process. However, as expressed by Jones (1957, p. 37). "The greatest political issues and the fate of statesmen were decided in the courts. Would it not be prudent for leading politicians to get their supporters to enrol in the 6000 jurors? They were not obliged to empanel themselves every day for minor cases, but could turn out in force when a cause celebre was to be tried." Consequently, the outcome of the lottery for position on the panel would likely give similar results in consecutive years. This further implies that the court system and the graphe paranomon helped stabilise Athenian policy. ${ }^{33}$

\footnotetext{
33 Hansen (1999, p. 182), suggests that there was a good deal of change in the 6000 panel, but also that there was competition for places. This is compatible with our argument that the strength of the support for a politician in the panel would probably not change much from 1 year to the next.
} 
The discussion above should by no means be taken to imply the Athenian court system and use of the graphe paranomon eliminated all uncertainty in Athenian politics. On the contrary there must have been many cases when politicians were unsure which way the vote would go not only in the Assembly but also in a court, and the Athenian voters must also frequently have been unsure who they should support and what were the likely consequences of the alternative policies being discussed. However it does seem to us that the degree of uncertainty probably was a lot less prominent than we have believed before. Nor is it claimed that the graphe paranomon was conceived with the view to elicit preferences or stabilise politics. These were side effects most probably both unforeseen and unintended. Yet, unforeseen consequences are a ubiquitous phenomenon and ancient Athenians quickly learnt how to make full use of the procedure in the context of the Assembly and the courts.

\section{Concluding remarks}

In truth, questions about institutions of collective decision making change little, if at all, through time. Understanding how other societies designed and operated such institutions, especially when they share democratic structures, provides new and illuminating insights. The institutions analyzed in this paper take on considerable interest as they tell us something not only about the ancient societies, but also provide lessons for those who consider direct democracy mechanisms in today's politics.

In contrast to modern parliamentary democracies, Ancient Athens was a direct democracy. In Athens there were no political parties, but a number of so-called politicians who competed with each other in trying to direct Athenian policy. The graphe paranomon prescribed for annulment of decrees passed by the Assembly and punishment for those who gave bad council in the Assembly. The graphe paranomon not only gave the Athenian citizens an opportunity to reconsider an issue where the Assembly had already made a decision, but also kept the Athenian politicians in line, preventing them from giving bad advice. Having suffered the consequences of some rash decisions in the fifth century, the Athenian citizens probably welcomed the opportunity to think twice over important issues, and to punish those who came up with bad ideas that were contrary to the long-standing principles of their democracy.

In the extensive literature on the ancient Athenian democracy, some interesting properties of the political and legal rules of the game seem to have escaped notice. The present study examined the content and consequences of graphe paranomon. Quantitatively, awards of honorary decrees were the largest part of the business of the Assembly, and a large part of all graphe paranomon lawsuits attacked such honorary decrees. We attributed the extensive award of honours by the Assembly to the wish of the demos to co-opt and motivate private individuals to contribute to the Athenian community life and fund public services, and increase their stake in the survival of the democracy. We have also showed that the graphe paranomon had several side effects that have largely gone unnoticed in the literature. Specifically, initiating graphe paranomon against politicians who proposed honorary decrees reduced the uncertainty regarding voter preferences about politicians, providing 
most valuable information to the politicians wishing to propose policies and lead Athens. This is an important feature, because it cannot have been easy for Athenian politicians to predict the preferences of the voters at an upcoming meeting of the Assembly. It was, for example, anybody's guess which selection of the eligible citizens would appear in the Assembly on any particular day. It is most likely that this made public policy less volatile than it would have been otherwise, a factor that helps explain the Athenian success in the fourth century.

The present analysis also highlights some of the fundamental differences between the ancient direct and modern representative democracy. In modern representative democracies citizens transfer significant discretionary powers to elected politicians, and instruments of direct democracy are occasionally complements rather than substitutes of indirect democracy. As a result representative government simultaneously requires accountability through representatives and accountability of representatives (Lord and Pollac 2010, p. 975). Competitive elections are an obvious mechanism to hold politicians accountable, but as choices are exercised several years apart additional mechanisms are put in place. These include formal state institutions like the judiciary for resolving disputes, the national audit office for checking financial propriety, and the ombudsman for investigating complaints against a public authority.

In the direct democracy of Athens there was no need for accountability through representatives. There was, however, accountability of the agents of the demos, both those who were appointed to administer public affairs, and those who with their proposals wished to lead the demos to particular outcomes. From a modern perspective, threatening politicians with the possibly severe punishment provided by the graphe paranomon would probably be against the grain of basic human rights, and discourage talented individuals to get involved in policy making. Not so for the ancient Athenians. Graphe paranomon was another manifestation of the participatory nature of the polity and supremacy of the demos. The demos in the form of the Assembly or in the form of the courts decided political institutions and policy within the institutions chosen; politicians knew that they were constrained by these rules.

\section{Ancient sources cited}

Demosthenes, 20.154, 24.215.

Thukydides, III. 1-49

Xenophon, Hellenika 1.7.1-35.

Acknowledgements We would like to thank three anonymous referees for several comments and suggestions that significantly improved the paper. We are, of course, responsible for any remaining errors and omissions.

Open Access This article is distributed under the terms of the Creative Commons Attribution 4.0 International License (http://creativecommons.org/licenses/by/4.0/), which permits unrestricted use, distribution, and reproduction in any medium, provided you give appropriate credit to the original author(s) and the source, provide a link to the Creative Commons license, and indicate if changes were made. 


\section{References}

Besley, T., \& Coate, S. (2008). Issue unbundling via citizens' initiatives. Quarterly Journal of Political Science, 3, 379-397.

Cammack, D. (2017). The democratic significance of the classical Athenian courts. In W. O'Reilly (Ed.), Decline: Decadence, decay and decline in history and society. Budapest: Central European.

Canevaro, M. (2015). Making and changing laws in ancient Athens. In E. M. Harris \& M. Canevaro (Eds.), The Oxford handbook of ancient Greek law. Retrieved 24 Feb 2015. http://www.oxfordhand books.com/view/10.1093/oxfordhb/9780199599257.001.0001/oxfordhb-9780199599257.

Cartledge, P. (2016). Democracy. A life. Oxford: Oxford University Press.

Carugati, F., Calvert, R., \& Weingast, B. (2016). Constitutional litigation in ancient Athens. Judicial review by the people themselves. Memo, retrieved 23 June, 2017. https://link.springer.com/content/ pdf/10.1007\%2Fs40803-017-0054-1.pdf.

Carugati, F., Hadfield, G., \& Weingast, B. (2015). Building legal order in ancient Athens. Journal of Legal Analysis, 7, 291-324.

Carugati, F., Ober, J., \& Weingast, B. (2016b). Development and political theory in classical Athens. Polis: Journal for Ancient Greek Political Thought, 33, 71-91.

Carugati, F., \& Weingast, B. (2018). Rethinking mass and elite decision-making in the Athenian lawcourts. In M. Canevaro, A. Erskine, B. Gray, \& J. Ober (Eds.), Ancient greek history and contemporary social science. Edinburgh: Edinburgh University Press.

D’Amico, D. J. (2018). The law and economics of sycophancy. Constitutional Political Economy. https:// doi.org/10.1007/s10602-018-9261-6.

Davies, J. K. (1971). Athenian propertied families. 600-300 B.C. London: Oxford University Press.

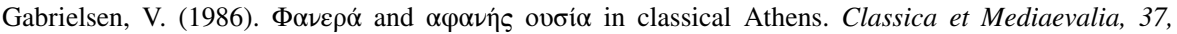
99-114.

Hansen, M. H. (1974). The sovereignty of the people's court in Athens in the fourth century B.C. and the public action against unconstitutional proposals (Vol. 4). Odense: Odense University Press.

Hansen, M. H. (1999). The Athenian democracy in the age of Demosthenes: Structure, principles and ideology. London: Bristol Classical Press.

Headlam, J. W. (1891). Election by lot in Athens. Cambridge: Cambridge University Press.

Jones, A. H. M. (1957). Athenian democracy. New York: Frederick Praeger.

Kahneman, D. (2011). Thinking fast and slow. New York: Farrar Straus Giroux.

Kron, G. (2011). The distribution of wealth at Athens in comparative perspective. Zeitschrift für Papyrologie und Epigraphik, 179, 129-138.

Lanni, A. (2009). Social norms in the courts of ancient Athens. Journal of Legal Studies, 1, 691-735.

Loomis, W. T. (1998). Wages, welfare costs and inflation in classical Athens. Ann Arbor, MI: University of Michigan Press.

Lord, C., \& Pollak, J. (2010). Representation and accountability: Communicating tubes? West European Politics, 33, 968-988.

Lyttkens, C. H. (1994). A predatory democracy? An essay on taxation in classical Athens. Explorations in Economic History, 31, 62-90.

Lyttkens, C. H. (2013). Economic analysis of institutional change in ancient Greece. Politics, taxation and rational behaviour. London: Routledge.

Lyttkens, C. H., \& Gerding, H. (2018). Understanding the politics of Perikles around 450 BC. In M. Canevaro, A. Erskine, B. Gray, \& J. Ober (Eds.), Ancient Greek history and contemporary social science. Edinburgh: Edinburgh University Press.

Matsusaka, J. G. (2004). For the many or the few: The initiative, public policy, and american democracy. Chicago: University of Chicago Press.

Matsusaka, J. G. (2005a). The eclipse of legislatures: Direct democracy in the 21st century. Public Choice, 124, 157-177.

Matsusaka, J. G. (2005b). Direct democracy works. Journal of Economic Perspectives, 19, 185-206.

Matsusaka, J. G., \& McCartny, N. M. (2001). Political resource allocation: Benefits and costs of voters initiatives. Journal of Law Economics and Organization, 17, 413-448.

McCannon. (2018). Arbitration in classical Athens. Constitutional Political Economy (under review).

Mueller, D. C. (1996). Constitutional democracy. Oxford: Oxford University Press.

Ober, J. (1989). Mass and elite in democratic Athens. Princeton: Princeton University Press.

Ober, J. (2008). Democracy and knowledge. Princeton: Princeton University Press. 
Ober, J. (2015). The rise and fall of classical Greece. Princeton: Princeton University Press.

Ober, J. (2017). Inequality in late-classical democratic Athens: Evidence and models. In G. C. Bitros \& N. C. Kyriazis (Eds.), Democracy and open economy world order. New York: Springer.

Rhodes, P. J. (1998). Enmity in fourth century Athens. In P. Cartledge, P. Millett, \& S. von Reden (Eds.), Kosmos. Essays in order, conflict and community in classical Athens. Cambridge: Cambridge University Press.

Schwartzberg, M. (2004). Athenian democracy and legal change. American Political Science Review, 98, 311-325.

Tridimas, G. (2010). Constitutional judicial review and political insurance. European Journal of Law and Economics, 29, 81-101.

Tridimas, G. (2012). Constitutional choice in ancient Athens: The rationality of selection to office by lot. Constitutional Political Economy, 23, 1-21.

Tridimas, G. (2016). Conflict, democracy and voter choice: A public choice analysis of the Athenian ostracism. Public Choice, 169, 137-159.

Tridimas, G. (2017). Constitutional choice in ancient Athens: The evolution of the frequency of decision making. Constitutional Political Economy, 28, 209-230.

Tsebelis, G. (2002). Veto players: How political institutions work. Princeton: Princeton University Press.

Yunis, H. (1988). Law, politics and the graphe paranomon in fourth-century Athens. Greek, Roman and Byzantine Studies, 29, 361-382. 